\title{
THE ANALYSIS ILLOCUTIONARY ACTS OF USTADZ HANAN ATTAKI, LC ON VIDEO UST. HANAN ATTAKI YOUTUBE CHANNEL
}

\author{
Ajrina Al Mar'atus ${ }^{1}$, Trisnendri Syahrizal ${ }^{2}$ \\ ${ }^{1}$ IKIP Siliwangi \\ ${ }^{1}$ ajrinalmaratus@student.ikipsiliwangi.ac.id, ${ }^{2}$ trisnendri@ikipsiliwangi.ac.id
}

\begin{abstract}
The purpose of this study to analyze type of illocutionary speech acts that used by Hanan Attaki and identifying speech acts utterance by Hanan Attaki on Youtube. The method used in this study is the qualitative descriptive method because this is done only based on the fact and the writer describes the result in from words and the explanation of the result. Data collection method that used is scrutinized method and make a script, is scrutinize use of language by Ustadz Hanan Attaki, then the data is note and classified based on type of illocutionary. In this result the writer analyze all type of illucationary speech act used by Ustadz Hanan Attaki on Video Ust. Hanan Attaki Youtube Channel. The result of this study found 65 clauses that contain the type of illocutionary speech acts, there are representatives (37), directives (22), declarative (5) and commissive (1) each type of the speech acts are delivering different meaning and representative is the most widely used by Ustadz Hanan Attaki. It fits with the illocutionary speech act theory as religious speech containing factual matters raised by religious leaders.
\end{abstract}

Keywords: Youtube, Pragmatics, Speech Acts, Illocutionary

\section{INTRODUCTION}

Youtube is a social media as a tool tp convey variety information in the form of videos that can be accessed through the internet by everyone to get the desired information. Youtube is one of the social media with a website that provides various kinds of videos ranging from video clips to films (Sholihatin, 2019). As well as videos made by Youtube users themselves we can use this social media easily on all mobile phones. So that it can be used anywhere and anytime to get variety information in fast time. Youtube is currently a very popular social in the millennial era, people use Youtube as a place to work by making videos that they want, on of which is Youtube used as a media for speeches or lectures aimed at giving advice and instructions so that, people can watch where just anytime and easily through cell phones. One of the most popular presentations or lectures recently was Ustadz Hanan Attaki's lecture on Youtube.

As a speaker requires a language to communicate to convey a message so that, the message spoken by speaker to the audience is conveyed well so that it can understand the contents of the message (Hutajulu \& Herman, 2019). To achieve the purposes of meaning in language, especially the meaning of the smallest clause contained in a person's speech requires a pragmatic to study so, as to produce the interpretation of the same meaning in a communication. Pragmatics is the study of meaning in relation to said situations which include the elements of greeting and those addressed, the context, objective, acts of speech allocation, time and place (Mufiah et al., 2018). Form the statement above, it can be concluded that pragmatic is a branch of linguistics that learns the meaning that is bound to accommodating context and the 
background of the language itself. The relationship between language and context is the basis of pragmatic understanding.

In this study, pragmatic include speakers, speech partners, speech and speech goals as speech acts, and speech as verbal action results (Sholihatin, 2019). Speech partners are people who interact or communicate with someone, the purpose of speech means the intention of the speaker to express something, while speech is a form of speech act or the outcome of a speech act. In the lecture given by the speaker, it can be used to express the intent and purposes of the speaker, in this case the speech will be studied as an illocutionary speech acts used by Ustadz Hanan Attaki in delivering lectures on Youtube.

Pragmatic, which is a relationship between language and context that explain the basic understanding of pragmatic language (Sintamutiani et al., 2019). This study of the ability of language users to connect sentences with the appropriate context in sentences. Context is very important in pragmatic studies, it can be concluded that pragmatic is a branch of science that studies speech meanings associated with the context of speech. According (Joni et al., 2018) stated Jhon L. Austin person who first introduced the term speech act in his book entitled How to do Things with Words in 1962. "Speak acts is the role of language in communicating social acts like requesting, questioning, promising, thanking, stating, as well as more institutional verbal like pronouncing sentence in court or performing ceremonies of baptizing, marrying". Speaking a certain sentence seen as taking action other than saying sentence.

Speech acts are divided into three, namely locution speech acts, illocutionary speech acts and perlocutionary speech acts (Dahlia et al., 2019). Locution speech acts is the act of saying something with the word and meaning of the sentence according to meaning of the word. Illocutionary acts are acts of doing something, namely talking about the intent, function or utterance of the person concerned. And perlocutionary speech acts is effects that speakers give by saying something. (Azizah \& Alpiah, 2018) in illocutionary speech acts divided into five types, there are: (1) representative speech act is an illocutionary act that represents a state of affairs (2) directive speech acts is an illocutionary act for getting the addressee to do something (3) expressive speech acts is an illocutionary act that expresses the mental state of the speaker about an event presumed to be true (4) commisssive speech acts is an illocutionary act for getting speaker the one performing the speech act to do something (5) declarative speech acts is an illocutionary act that brings into existence the state of affairs to which it refers. Based on the description above, the purposes of this study is to describe the form of illocutionary speech acts used by Ustadz Hanan Attaki on Youtube with the title "The Analysis Illocutionary Acts of Ustadz Hanan Attaki, Lc on Video Ustadz Hanan Attaki Youtube Channel”

\section{METHOD}

Method is the steps that the writer do to collect the data or information. Research design can be classified into three board categories there are quantitative research, qualitative research, and mixed methods research design. In this study the writer used descriptive qualitative. Qualitative research is intended to understand phenomenon of what is experience by subject of research such as behavior, perception, motivation action holistically and by way of description in the form of words and language, in a specific natural context by utilizing various scientific methods (Setiani \& Utami, 2018). The data of this study are the illocutionary speech act of Ustadz Hanan Attaki on Youtube http://youtu.be/DbZ5RdLZry4. This website contains a collection of lectures by Ustadz Hanan Attaki which are presented in video form. The subject of this study was Ustadz 
Hanan Attaki. The informant of this study was Ustadz Hanan Attaki who gave a lecture at a grand tabligh event in an area.

The method used in this study the method of referring to the advanced technique of capable free-listening technique. In this technique the writer is not directly involved in dialogue or conversation, the writer is only an observer and listens to what the speaker say and then make a scrip to analyze the word and sentence form by mentioning its type of illocutionary acts (Rahayu, Syahrizal, Sadikin 2019). The first, collecting the data in the form of video lectures by Ustadz Hanan Attaki. Second, transcribing the oral speech of Ustadz Hanan Attaki's video in writing. Third, identify the data based on type of illocutionary speech act. Fourth, classify data based on type of illocutionary speech act. Fifth, analyze the data that has been classified, and sixth conclude the research data.

\section{RESULTS AND DISCUSSION}

\section{Results}

The data found in this study are there are five types: representative, directive, expressive, commissive and declarative. The writer also found that representative act is the type that mostly performed by Ustadz Hanan Attaki on Video Ust. Hanan Attaki Youtube Channel.

Table 1. Illocutionary acts result on Ustadz Hanan Attaki

\begin{tabular}{ccc}
\hline No & Illocutionary Acts & Sentences/amount \\
\hline 1. & Representatives & $37 / 65$ \\
\hline 2. & Directives & $22 / 65$ \\
\hline 3. & Declaratives & $5 / 65$ \\
\hline 4. & Commissive & $1 / 65$ \\
\hline 5. & Expressive & $0 / 65$ \\
\hline
\end{tabular}

\section{Discussion}

Based on findings, the writer found 4 types illocutionary act in the utterance of Ustadz Hanan Attaki. Every data from type illocutionary act is taken by a sample sentence. The data below is the type of illocutionary act. The writer divides the sentence by type of illocutionary act by Yule in (Amanda et al., 2018).

\section{Representatives}

\section{Data 1}

"Sholat is the way leave us from the sin, innas-sholata tan-ha 'anil-fahsya 'iwal-mungkar" The words in underline are representative because it shows that the speaker asserts the fact to the listener that prayer can leave sin behind and supported by indeed prayer prohibits immorality and wrongdoing contained in the Qur'an surah Al-Ankabut ayat 45 [29:45]. According to Yule in (Amanda et al., 2018) said representative represented assert the fact. Based on the Merriam-webster dictionary the facts are a piece of information presented as having objective reality in accordance with the prayer sentence is the way to leave us from the sin which is then supported with sentences in the Qur'an as facts. So, the sentence prayer is the way leave us from the sin, innas-sholata tan-ha 'anil-fahsya' iwal-mungkar including representative because the facts provides a piece of information presented as having objective reality.

Data 2

"Now it has been proven that prayer is really prohibits immorality and wrongdoing" 
The word in underline are representative because it shows the speaker says the fact and supported by proven word, this shows is a truth has already happened and produced something. According to Yule in (Amanda et al., 2018) said representative represented a stating opinion of fact. Based on Meriam-webster dictionary proven are to demonstrate as having a particular quality or worth in accordance with now it has been proven that prayer is really prohibits immorality and wrongdoing is then supported with sentences in the Qur'an as facts. So, proven including representative because proven are to demonstrate as having a particular quality.

\section{Data 3}

\section{"Maybe our prayers are still not on time"}

The word in underline is representative because it shows the speaker expresses an opinion with predictions supported by possible word. According to Yule in (Amanda et al., 2018) said representative represented predict. Based on Merriam-webster dictionary the word of maybe is perhaps as predict and predict are to indicate in advance in accordance with maybe our prayers are still not on time. So, predict including representative because predict are to indicate in advance.

\section{Data 4}

"Oh maybe our prayers haven't been in the first prayer"

The word in underline is representative because it shows the speaker expresses an opinion with predictions supported by possible word. According to Yule in (Amanda et al., 2018) said representative represented predict. Based on Merriam-webster dictionary the word of maybe is perhaps as predict and predict are to indicate in advance in accordance with oh maybe our prayers haven't been in the first prayer. So, predict including representative because predict are to indicate in advance.

\section{Data 5}

"Oh maybe we haven't added much prayer to the sunnah gimmick"

The word in underline is representative because it shows the speaker expresses an opinion with predictions supported by possible word. According to Yule in (Amanda et al., 2018) said representative represented predict. Based on Merriam-webster dictionary the word of maybe is perhaps as predict and predict are to indicate in advance in accordance with oh maybe we haven't added much prayer to the sunnah gimmick. So, predict including representative because predict are to indicate in advance.

\section{Data 6}

\section{"Oh maybe our prayers are still not in the mosque"}

The word in underline is representative because it shows the speaker expresses an opinion with predictions supported by possible word. According to Yule in (Amanda et al., 2018) said representative represented predict. Based on Merriam-webster dictionary the word of maybe is perhaps as predict and predict are to indicate in advance in accordance with oh maybe our prayers are still not in the mosque. So, predict including representative because predict are to indicate in advance.

\section{Data 7}

"Oh maybe our prayers have not been closed with many prayers, prayers and so on" The word in underline is representative because it shows the speaker expresses an opinion with predictions supported by possible word. According to Yule in (Amanda et al., 2018) said representative represented predict. Based on Merriam-webster dictionary the word of maybe is perhaps as predict and predict are to indicate in advance in accordance with oh maybe our prayers have not been closed with many prayers, prayers and so on. So, predict including representative because predict are to indicate in advance.

\section{Data 8}


"Prayer is good, it is not in vain, wasta'inu bis-sabri was-shalah wa innaha lakabiratun illa 'alal-khasyi'in"

The sententce in underline are representative because it shows that the speaker asserts the fact to the listener that prayer is kindness and supported by and seek help through patience and prayer and indeed it is difficult expect for the humbly submissive to Allah contained in the Qur'an surah Al-Baqarah ayat 45 [2:45]. According to Yule in (Amanda et al., 2018) said representative represented assert the fact. Based on the Merriam-webster dictionary the facts are a piece of information presented as having objective reality in accordance with the prayer sentence is the way to leave us from the sin which is then supported with sentences in the Qur'an as facts. So, the sentence prayer is good, it is not in vain, wasta'inu bis-sabri was-shalah wa innaha lakabiratun illa 'alal-khasyi'in including representative because the facts provides a piece of information presented as having objective reality.

\section{Data 9}

"Already started to gradually reduce even though it could not be maximized"

The word in underline is representative because it shows the speaker wants to report something to the listener in the form an action and supported by already done something. According to Yule in (Amanda et al., 2018) said that representative represented a report. Based on Merriam-webster dictionary already are prior to a specified or implied past, present or future time and report are common talk. So the word already including representative because the report are common talk.

\section{Directives}

\section{Data 1}

"Do not get caught in the traps of Satan"

The word in underline is directive because it shows the speaker warns to the listener a prohibition and dangerous warning so we can avoid the pitfalls of the devil which is harmful. According to Yule in (Amanda et al., 2018) said that directive represented a warning. Based on Merriam-webster dictionary do not including warn and warn are to give notice to berforehand especially of danger or evil. So, the word of do not including directive because do not as warn and warn are to give notice to beforehand especially or danger or evil.

\section{Data 2}

"Improve your pray, God will fix ourselves from sin"

The word in underline is directive because it shows the speaker gives a command to the listener to be carried out in order to avoid danger and get safety. According to Yule in (Amanda et al., 2018) said that directive represented a command. Based on Merriamwebster dictionary improve are to enhance in value or quality make better. So, the word of improve as command and improve are to enhance in value or quality make better.

\section{Data 3}

"Then better your prayers to improve, Allah will improve our lives"

The word in underline is directive because it shows the speaker gives a command to the listener to be carried out in order to avoid danger and get safety. According to Yule in (Amanda et al., 2018) said that directive represented a command. Based on Merriamwebster dictionary improve are to enhance in value or quality make better. So, the word of improve as command and improve are to enhance in value or quality make better.

\section{Data 4}

"Don't close the heart"

The word in underline is directive because it shows the speaker warns to the listener a prohibition and dangerous warning so we can avoid the pitfalls of the devil which is 
harmful. According to Yule in (Amanda et al., 2018) said that directive represented a warning. Based on Merriam-webster dictionary do not including warn and warn are to give notice to berforehand especially of danger or evil. So, the word of do not including directive because do not as warn and warn are to give notice to beforehand especially or danger or evil.

\section{Data 5}

"Summum-bukmum umyuun, that danger"

The word in underline is directive because it shows the speaker warns to the listener a prohibition and dangerous warning so we can avoid the pitfalls of the devil which is harmful. According to Yule in (Amanda et al., 2018) said that directive represented a warning. Based on Merriam-webster dictionary do not including warn and warn are to give notice to berforehand especially of danger or evil. So, the word of do not including directive because do not as warn and warn are to give notice to beforehand especially or danger or evil.

\section{Declaratives}

\section{Data 1}

"Means that prayer builds our faith"

The word in underline is declarative because it shows the speaker declares something that shows is a truth and must be informed supported by an explanation that has been submitted about the importance of prayer. According to Yule in (Amanda et al., 2018) said that declarative represented declare. Based on Merriam-webster dictionary the word of means are to have in the mind as a purpose including declare. So, means including declarative as declare because means are to have in the mind as a purpose.

\section{Data 2}

"There is no good in vain!"

The sentence above is declarative because it shows the speaker decides with clarify his words with previous explanation related to the importance of prayer with the firmness of the word supported there is none, that goodness is not vain. According to Yule in (Amanda et al., 2018) said declarative represented decide. Based on Merriam-webster dictionary the word of there is no are certainly true, real and cannot be avoided or denied as decide. So, there is no including declarative as decide because there is no are certainly true, real and cannot be avoided or denied.

\section{Data 3}

"There is no denying the heart, because menghijabi is something bad"

The sentence above is declarative because it shows the speaker decides with clarify his words with previous explanation related to the importance of prayer with the firmness of the word supported there is none, that goodness is not vain. According to Yule in (Amanda et al., 2018) said declarative represented decide. Based on Merriam-webster dictionary the word of there is no are certainly true, real and cannot be avoided or denied as decide. So, there is no including declarative as decide because there is no are certainly true, real and cannot be avoided or denied.

\section{Commissive}

\section{Data 1}

"Hopefully we will gradually improve"

The word in underline is commissive because it shows the speaker hope something from himself and the listener and supported by hopefully to be better. According to Yule in (Amanda et al., 2018) said that commissive represented hope. Based on Merriam-webster dictionary hopefully are in way that expresses desire with an expectation of fulfillment as 
hope. So hopefully including commissive because hopefully are in way that expreses desire with expectation of fulfillment.

After the writer analyzed illocutionary act of Ustadz Hanan Attaki on Youtube, the data found that are 65 clauses. Each clause has own speech act are representative act is a speech act that binds the truth of the information spoken by speaker such as states, reports and predict. Directive act is speech act that give rise to several affect through the actions of the partner such as command, warning and suggest. Declarative act is speech act performed by speaker with the attention of creating a thing that is not same as the reality when before the speaker pronounces declarative act such as declare and dicide. The last commissive act is speech act that bind speaker with a future action such as promise.

\section{CONCLUSION}

Illocutionary acts as one of the utterance action strategies are often used in utterance of Ustadz Hanan Attaki. Based on data analysis, there are four findings of this study. As shown in the first finding, there are four types of illocutionary act used by Hanan Attaki in his lecture which are representative, directive, declarative and commisive. From a total of 65 utterance that contain illocutionary acts are representative 37 clauses, directive 22 clauses, declarative 5 clauses and commissive 1 clause. The percentage of events is representative $(56,9 \%)$, directive $(33,8 \%)$, declarative $(7,7 \%)$ and commssive $(1,6 \%)$. In conclusion illocutionary act can reveral the speaker's acti beyond what he said. By analyzing the illocutionary act used by Ustadz Hanan Attaki, the writer concluded that Ustadz Hanan Attaki mostly commited representative act that refer to state, report, predict and informing with a number of times inviting in goodness in his lectures about "Perbaiki dengan Sholat by Ustadz Hanan Attaki".

\section{ACKNOWLEDGMENTS}

Allhamdulillahirrobil'alamiin, praised to Allah SWT., Lord of the world, who has given the writer His love and compassion to finish this journal entitled: The Analysis Illocutionary Act of Ustadz Hanan Attaki on Viedo Ustadz Hanan Attaki Youtube Channel. This journal is a requirement for accomplishing S-1 degree in English Education Departement, IKIP Siliwangi.

The writer want to deliver my sincere thanks to Trisnendri Syahrizal, S.Pd., M.Hum. as adviser which has helped to finish this study. Thank you for meaning full advice, correction, suggestion and spirit. I would like to thank our parents, family and friend for their endless love in giving us support morally, motivation and material support.

\section{REFERENCES}

Amanda, V., Marlina, L., Padang, U. N., Levinson, T., \& Introduction, A. (2018). Directive Speech Acts Used in Frozen Movie Transcript. E-Journal of English Language and Literature, 7(1).

Azizah, A. N., \& Alpiah, D. (2018). An Analysis of Illocutionary Acts Performed in Donald Trump's Victory Speech in The United States Election 2016. 01(03), 241-248.

Dahlia, N. S. F., Lina, N., \& Yugafiati, R. (2019). An Speech Act Used by Anna as The Second Characters in "Frozen" Movie Transcript. Project: Professional Journal of English Education, 2(5), 628-633.

Hutajulu, F. S. L., \& Herman. (2019). Analysis of Illocutionary Act in The Movie "You Are My Home” English Subtitle. JEES: Journal of English Educational Study, 2(1), 29-36. 
Joni, T., Aristo, V., \& Ege, F. (2018). The analysis of speech act in a comic conversation. Journal of English Educational Study, 1(1), 34-42.

Mufiah, N. S., Yazid, M., \& Rahman, N. (2018). Speech Acts Analysis of Donald Trump ' S Speech. Project: Professional Journal of English Education, 1(2), 125-132.

Rahayu, A. S., Syahrizal, T., \& Sadikin, I. S. (2019). Speech Act Analysis of " Frozen " The Movie Script. Project: Professional Journal of English Education, 2(5), 692-699.

Setiani, A., \& Utami, D. P. (2018). An Analysis of Illocutionary Act In " How To Train Your Dragon 2 " Movie. Project: Professional Journal of English Education, 01(03), 225-234.

Sholihatin, E. (2019). An Analysis of Illocutionary And Perlocutionary. Journal of Languages and Language Teaching, 7(1), 46-56.

Sintamutiani, D. P., Fitriani, D., \& Inayah, R. (2019). An Analysis of Speech Act Classification In. Project: Professional Journal of English Education, 2(4), 429-435. 